\title{
SFL- BASED ANALYSIS OF THEMATIC STRUCTURE OF THE QUR'ĀN (19:41-50): SOME REFLECTIONS
}

\author{
Zaid Alamiri
}

\begin{abstract}
The present study is an endeavor to explore applying Systemic Functional Linguistics (SFL) to the oldest Arabic text (the Qur'ān). The study point of departure is the textual metafunction (of the Sura 19:41-50), focusing principally on thematic structure (Theme-Rheme) for its role first in organizing the linguistic resources of both the experiential and interpersonal meanings in text production; and secondly in message unfolding. The salient results are the followings: the use of the three types of Theme (i.e., textual, interpersonal and topical). The topical Theme, important in message unfolding, it is essentially realized by the verbal group in the declarative clause. By virtue of verbal inflection, the bound pronominal markers, expressing Subject in Mood system and the Participant in the transitivity system, expands Theme boundary to better reflect Arabic clause structure. As to Theme orientation, the semantic aspect of Theme function, it is seen that the interaction of the verbal-locution- projection, modalization of Theme, in particular, and other elements contributed to the saliency of interpersonal meanings. Though the Qur'ānic Arabic, of this narrative, lends itself for SFL analysis, the results should be interpreted as an approximation that needs further studies. That Theme, in this study, is register specific is too early to consider as comprehensive analysis of Qur'ānic narrative register is required to support these results. Finally, analyzing the Qur'ānic Arabic provides a support for SFL universality; and at the same time, SFL, as a sociosemiotic linguistic theory, offers new avenues to better understand the Qur'ānic texts in many ways.
\end{abstract}

Keywords: SFL; Textual Metafunction; Theme-Rheme Structure; Qur'ānic Narratives

\section{INTRODUCTION}

Systemic Functional Linguistics, (henceforth, SFL) is largely based on the description of the English language as a model, in building and developing its theory. And because SFL lacks an inherently typological orientation, language universals have not played a major role in it (Butler and Taverniers 2008,2- 
23). However, this situation had changed slightly since more typologically different languages have applied the model (Halliday and Matthiessen 2014, xviii; 54) amounting so far to fourteen.

Our study of the Qur' ānic Arabic, a variety differs from other varieties of Arabic, in particular Modern Standard Arabic, is a modest step that follows in this approach. This approach, of analysing the Textual metafunction, stems from the fact that there are 'universal' features of language, a point Halliday made explicit earlier in that metafunctional hypothesis is applicable to other languages, though under different assumptions and conditions (2000/1994,F59-60). The importance of analysing the textual metafunction resides, as its name indicates, in its role in text production, message unfolding and the relevance to its context. It follows that the textual metafunction function enables the experiential and interpersonal meanings to be actualized (Halliday, 1978:113); and thus it finally makes difference between 'text' and 'non- text'. The analysed text is a short pericope of a Qur' ānic narrative (Q 19:41-50), with the focus on two important features of the thematic structure (Theme-Rheme). The first essential one is Theme boundary recognition criterion. That is, how experiential Theme is realized; what element of transitivity system in Arabic clause occupies Theme position, especially in the verb-initial clause. Therefore significant space will be dedicated to discuss related aspects; for example, the extension of thematic range to include more than one element of experiential content. This is based on the fact that the verbal inflection, in Arabic, expresses the systems of person, tense, gender and number. Our interest, however, is in the person system realized by pronominal markers bound to the verbal group because of their relevance to the Subject in Theme position. The second central point highly pertinent to thematic structure, which will be elaborated on in detail, is Theme function or orientation since the textual metafunction roles is to organize the linguistic resources of the experiential and interpersonal metafunctions. Theme selection, therefore, influences the process of the unfolding and development of message meaning. Finally, this study hopes to be a step in a new approach to better understanding the Qur'ān as a social semiotic text.

\subsection{Some essential points on the Qur'ān}

The Qur'ān is considered the oldest and first actual book-length production of Arabic literature (Böwering 2003, 347; Fatani 2006, 356-357). The term, the Qur'ān, revolves around meanings related to oral discourse (Graham 1984,364-365); among the words denoting this relevance are tala occurring 63 times, and qara 'a, mentioned roughly 70 times, both indicating "reading" and or "reciting" (Günther 2003,188-189). More importantly, the Qur'ān use of a dynamic and interactive communication with its audience and 
addressees explicitly expresses its orality character (Paret 1983, 200; Neuwirth 2006, 145). ${ }^{1}$

Regarding its language, the Qur'ān repeatedly defines itself as being a plain and clear Arabic tongue (speech, language). ${ }^{2}$ The controversial questions concerning the status of Arabic during the revelation or pre-Islamic days are beyond our scope. ${ }^{3}$ It suffices to mention that its language, generally speaking, is similar to the high Arabic language of pre-Islamic poetry, though it different from in many aspects displaying 'certain peculiarities' at the levels of structure, syntax, lexis (vocabulary), pronunciation and semantics (Paret 1983,196-199; Versteegh 2014,65). Secondly, the so called Modern Standard Arabic is different from the Qur'ānic Arabic. ${ }^{4}$

Compared to other scriptures, the Qur'ān is 'a fairly compact text' that should not be viewed as a monolithic, but rather as a collection of independent text units (Neuwirth 2007, 97-98). That is, its text involves different registers as viewed from an SFL perspective. The Qur'ann bears the elements and features of text that serves a function in the life of the community. It exhibits features of texture that define a text as such. These features of textuality are principally realized by the cohesive ties. ${ }^{5}$ These ties, realized by lexicogrammatical devices, set up the semantic relations between text parts.

Closely linked to this is the notion of 'text' (النصّ". This term in Arabic generally conveys meanings of unfolding and differentiation (i.e., being obvious and apparent) (Abu Zayd 1995, 150-159). ${ }^{6}$ Its development in the Qur'ānic scholarship, however, provokes misinterpretations; it-'text'- had turned, since the thirteen century, into a more authoritative consideration of the whole Qur' ān as a 'text" ${ }^{7}$, in comparison to its initial meaning taken for plain self-evident passages (of the Qur'ān) that need no explanation (ibid).

\footnotetext{
${ }^{1}$ The most salient element of this orality is the frequent use of the speech denoting verb 'say' in its different forms. It is occurred over one thousand. For example, the form 'said'- for third person masculine singular- is mentioned 529 times; and 332 times for third person masculine plural; the imperative 'say-you' for second person masculine 327 times form. Besides, the first Sura (Q 96:1) started with 'recite in the name of your Lord'. The other element is the use of vocatives which presupposes the existence of audience addressed.

2 These are some examples: Q16:103; Q26:195; Q39:28. The word of 'Arabic' was mentioned ten times.

${ }^{3}$ This particular point has been widely discussed, see for example Versteegh 2014.

${ }^{4}$ MSA (MWA as Badawi calls it), though it is based on classic Arabic (CA), differs from in many aspects. MSA has been influenced heavily by syntactic, lexical and stylistic features of western languages (Ditters, 1992, 5; Badawi et al, 2016, 3). For detail, see Versteegh (2014, 233-238).

${ }^{5}$ It refers to Reference, Substitution, Ellipsis, Conjunction and Lexical cohesion (Halliday and Hasan 1976).

${ }^{6}$ For a full account of meanings of the 'text', see Abu Zayd, 1995 "Text, Authority and Truth (in Arabic) and his other related works.

${ }^{7}$ There is no personal opinion (Ijtihad) where there is a text (i.e., Qur'ān).
} 


\section{OUTLINE OF SFL}

Language, in the view of SFL, is a social semiotic system (meaningmaking resource), which always takes place in context. This view, which integrates the functional aspect (of language) with its social orientation, two essential features of SFL theory, accounts for the evolution of language in human society to serve the broad needs of "construing a reality and enacting interpersonal relationship" (Halliday 2007/1978,256). And this focus is "much more fully developed' in SFL than in other functional theories (Butler, 2003, $\mathrm{v} 1: 44,153,156$ and 168), which makes SFL distinct from other theories in that it is "truly a theory of language, not only grammar, since it strives to account for how language enables human beings to communicate with one another in the ways they do" (Butler, 2009, 63-64, cited in Fontaine et al., 2013, 95). It follows then that the grammar of a language is not an inventory of structures but a resource for making meaning, in which explaining something is based not on "how it is structured but in showing how it is related to other things (Halliday and Matthiessen 2014,49).

\subsection{Metafunctions: modes of meaning}

Based on the above, language is organized into three strata: semantic, lexicogrammatical and phonological. These strata are considered as systems and each system, in turn, is a system of meaning potential, which consists of a range of options (Halliday, 1978,39). Language is, then, a network of interrelated meaningful options from which the speaker/writer selects "either this, or that, or the other', 'either more like the one or more like the other', and so on" (Halliday 2000/1994, F40).

The semantic stratum, which is related by means of realization with the two other strata (lexico-grammatical and phonology), organizes the linguistic resources (of a clause) into three modes of meanings (metafunctions): ideational, interpersonal and textual. In the ideational, language serves for the expression of experience of the real world and of the world of consciousness (language as reflection); the interpersonal is concerned with establishing and maintaining social relations (language as action), and finally, the textual is where the language makes links with itself and with features of the situation in which it is used (language as relevance) (Halliday and Matthiessen 2014). It follows that each metafunction has its own system of networks, that is, TRANSITIVITY, MOOD, and THEME, respectively.

More importantly, these three metafunctions are not separate systems; rather they have equal status and importance in their simultaneous contribution to the meaning in every act of language user (Halliday 1978,112). That is, the text is a product of all of these metafunctions, which are simultaneously incorporated in its analysis. This means that the networks of options available to the user of the language correspond to these basic 
metafunctions of language. Nonetheless, each metafunction can be analysed separately into its respective systems, a possibility not available in other functional theories (Butler 2003, v1, 44-45,168). In this study, we are analysing only the textual metafunction.

\subsection{Textual metafunction}

Of the three metafunctions of SFL, the textual is the more disputed in terms of definition and boundary recognition, in particular thematic structure. The focus of this metafunction is on text-internal relationships, as well as on relationships of relevance between text and situation. Thus, its domain is related to the construction of the text in which it works as an enabling or facilitating metafunction, since both the ideational and interpersonal "depend on being able to build up sequences of discourse, organizing the discursive flow, and creating cohesion and continuity as it moves along" (Halliday and Matthiessen 2014,30-31). Thus the textual metafunction allows both the speaker / writer to construct "texts", and the listener / reader to distinguish a text from a random set of sentences. In other word, speaker-oriented choice is reflected in thematic structure, and listener-oriented choice in the distribution of given and new information (Halliday and Matthiessen 2014, 120). The textual function thus "constructs ideational and interpersonal meanings as information that can be shared by the speaker and the addressee; and it makes this sharing possible by providing the resources for guiding the exchange of meaning in text (Matthiessen 1995, 22). This double-sided function represents its second-order nature (as an enabling function) of creating a "semiotic reality - reality as meaning- brought into existence by drawing the ideational and interpersonal mode of expression into textual service, as carrier of textual waves" (ibid,53). Due to its particular nature, its components are perhaps the hardest to interpret and represent among the three metafunctions (ibid, 37-38), because, unlike the ideational that embodies a theory of reality as interpretation and representation, the textual is not a representational one in that it cannot be turned back on itself to REPRESENT itself as the ideational does. And it needs to be articulated in terms of the ideational metafunction" (ibid. Uppercase in original).

In terms of its components, the textual metafunction consists of three structures: thematic structure system (Theme-Rheme); information structure system, presenting the same content as (Given and New); and non-structural system of cohesive relations (grammatical and lexical devices). In this review our focus is only on the thematic system of the text, taken as written, highlighting only the Theme of its two important aspects, definition (semantic) and recognition (realization structure). However, some of the cohesion system ties would be touched on very briefly in section 4.3. 


\subsection{Theme: definition, recognition, and limitation}

The clause, as a message, is organized in such a way as to make the flow of discourse possible and effective (Halliday and Matthiessen, 2014, 88). This organization consists of two parts, Theme and Rheme. Theme, however, acquired a special place in the message of being its point of departure, and of locating and orienting the clause within its context. That is, it is what sets the scene for the clause itself and positions it in relation to the unfolding text. As such it bears and conveys part of the meaning of any clause, and contributes to the coherence and success of the message. It follows that Theme prominence in the message is to guide the addressee in "developing an interpretation of the message", and enables him "to process the message" (ibid, 89). The Rheme is everything that is not Theme: it is the part of the clause where the Theme is developed. What is explained above is the semantic aspect (definition) of Theme. Its other aspect of recognition (the view from below) can be seen in the fact that in the English clause, it is expressed by the first group or phrase that has some function in the experiential structure of the clause, i.e., participant, process, or circumstance (Halliday and Matthiessen 2104,91). This means that it ends with the first constituent of the transitivity system, which is referred to as the experiential Theme $^{8}$, differentiating it from the other two kinds of theme (Textual and Interpersonal). It follows that Theme contains one, and only one, of these experiential elements; the most common type is a participant, realized by a nominal group. This realization criterion of Theme conflates with an interpersonal function as well, i.e., in the choice of Mood. This implies different types of themes according to the type of clauses in terms of speech functions realized by the Mood system. Generally speaking, in the declarative Mood, Theme is conflated with Subject, which is the unmarked type as compared to the marked Theme realized by other components of the transitivity system (ibid,97).

The Theme, in its two aspects of definition and recognition, has not escaped criticisms from inside and outside SFL circles. In this regard, Hasan and Fries's (1995) critical comments are still valid in highlighting many contentious problems in relation to Theme. The important insights, they highlighted, serve as a fair introduction to this discussion our topic. Our concern, due to lack of space, is limited only to the point of boundary (recognition: view from below) in declarative clauses for its close importance relevance to our study. That is, the consideration of Theme as the first element of transitivity system encountered in such clauses. Discussing cases of marked Theme in English, researchers are not agreed over this criterion. Some have argued that the Theme boundary should be extended to cover Subject, beside

\footnotetext{
${ }^{8}$ Thompson $(2013,163-164)$ suggests using experiential rather than topical to avoid confusion with the term 'topic'.
} 
the other elements of the transitivity system preceding it. The topic is widely discussed and tackled from different angles. Berry, for example, (1995, 1996 cited in Forey 2002,54-55), holds that Theme need not necessarily be only the first ideational element in a clause because, she argues, if only the first ideational element is analysed as Theme, then some co-referential elements will not be captured by an analysis of Theme in a text. Ravelli (1995) introduced a different argument based on the view that thematic path is not closed until Process is reached, at which point Rheme starts, as she showed in the following example: "and there this morning protesters gathered again at dawn" (Ravelli 1995, 223-225). Here, both 'this morning' and 'protesters' , she argued, could be taken to be within 'the point of departure' because Theme is not yet fully elaborated and further elements need to be considered. Differently stated, both 'this morning' and 'protesters' could be Subject; and "the Subject, from a dynamic perspective, indicates a core element of the clause around which a great deal of information hinges" in particular its role in understanding thematic development (ibid.). Thus, according to this view, Theme still continues until the point at which the clause enters on the Rhematic path. And thus, 'Halliday's explanation of the departure point of the message' will be broadened.

The argument behind this broadening of the Theme boundary is that nonSubject Themes function as 'framing elements', which are used as a signal for showing a step or a stage in the progression of the text, or as a change in focus, whereas Subjects are seen as 'recurrent elements' (Forey 2002,77). Montemayor-Borsinger, however, $(2011,74)$ has argued against this, and contends that when Subject stands alone as an unmarked experiential Theme, it embodies all the meaning within Theme, and thus has full 'thematic force', but it loses some of its 'thematic force' when it follows a marked theme, as some of this is taken up by what precedes it.

In our analysis of Theme, we adopt a somewhat different approach, in particular in relation to clauses starting with a verbal group (Process). We broaden the range of Theme by incorporating two experiential elements to better express the features of Arabic rather than imposing English model. This will be elaborated in detail in the section dealing with results and discussion.

This brief review highlights the fact that, as Hasan and Fries maintain, the discussion on Theme "is still surrounded by unresolved problems", and lacks clarity; and that the presence of alternative views is an indication of the problematic nature of the recognition criteria (1995: xxix). Other scholars have expressed similar concerns about the lack of clarity of the two features of definition and recognition of Theme (Thompson 2006, 658; 2007, 675; Lavid et al 2010, 297; Montemayor-Borsinger 2011, 68-72). 


\section{THEMATIC NOTIONS IN ARABIC LINGUISTIC TRADITION}

Although traditional Arabic linguistic theory is generally believed to be formally oriented, functional related concepts are not absent. It suffices to present here a very brief general account of thematic notions, highlighting some points of importance. ${ }^{9}$ To start with, the terms Mubtada' and Xabar (المُبندأ والخبر), used for the constituents of the nominal clause, are the most pertinent references to thematic structure; and often the pair Musnad' IlayhiMusnad (المُسند إليهـ المُسند) is considered to be the equivalent (Anghelescu, 2006, v4, 484). Such thematic concepts were first touched on by Sibawayh (d.796 CE) in some sections of his Book (al-Kitab) (1988 v1,23; v2,77-78, $88,126,128,129$ and 389); though the main entry was in a separate short chapter (v1:23). Sibawayh used different terms that bear relevance to thematic structure elements such as 'ibtida' (thematization), topicalisation, theme and Rheme as well as 'Isnad ${ }^{10}$ (predication); the theoretical considerations, of these terms, were critically reviewed and debated (Levin, 1981; Talmon, 1987; Goldenberg, 1988; Versteegh, 2007; and Peled, 2009). Marogy (2010) holds that these terms carry the concept of both Subject/topic and Theme, respectively. Moreover, the concept of 'ibtida', which means beginning, has two strands of meaning in Sibawayh's interpretation of the predication structure (الإسناد) (Mubtada'-Xabar; Theme-Rheme), viz., thematization and topicalisation. As to thematization or thematic 'ibtida', it is advanced as a term intrinsically linked to the 'initial position' and is used to gloss the pragmatic structure of Theme-Rheme (المسند والمسند اليه whereas the topicalisation or topical 'ibtida' corresponds to the syntactic structure of Mubtada'-Xabar: subject/topic-predicate (Marogy, 2010, 180). It follows that Sibawayh treatment, of Mubtada'-Xabar, highlighted, beside the structural aspects, the communicative aspects that establish and control the speaker/listener interaction. A careful reading of Sibawayh's Book reveals that he looked at language as being a kind of social interactional communication, between a speaker and a listener, always occurring in a context ( Carter 2007,186; al 'Awādy 2011).

The latter grammarians expanded Sibawayh's treatment of the subject and provided some important ('functional') insights of thematic structure concept. These points are ubiquitous and have been discussed in many linguistics treatises, traditional and contemporary; we limit ourselves to some works of traditional linguists. In these treatises the semantic aspects of the predicative relation, in particular the communicative value of the interaction between speaker and listener, were brought to the fore. These aspects are even more pertinent in the treatises of the rhetoricians. The Mubtada' was seen as being

\footnotetext{
${ }^{9}$ For more, see Baalbaki 2008.

10 'Isnad refers to both semantic and syntactic relations between the main constituents of the sentence (Versteegh, 2007,435).
} 
both the point of departure (and a topic of the speech), as well as being the given (old) information. For example, the noun that occupies the Mubtada' position should meet some requirements; the foremost one is the definiteness. In this regard, Ibn as-Sarraj (1996 [d.928 CE], v1, 58-62) said "in mentioning the definite noun in the beginning you draw the listener's attention to what you are talking about, as he waits for you to inform him the thing he does not know; thus the function of the Xabar is to predicate the Mubtada'. For example, in the clause (عبداله جالس) 'Abdullah [is] sitting), the truth and falsity reside in the Rheme ('the sitting'), and not in 'Abdullah because the informative value is related to, and occurs in, 'Abdullah's sitting (Rheme). 'Abdullah is mentioned to predicate the 'sitting' of him (ibid, 62). In other word, the value of communication resides in the Xabar, i.e., it is the element that which the listener benefits of, and with the Mubtada' it forms meaningful speech (Ibn 'Usf̣urr, 1982[d. 1263-70 CE], 340). Peled (2009, 22) ${ }^{11}$ asserts that this argument, i.e., that Mubtada' should in principle be definite, and the Xabar indefinite, is strikingly similar to any modern pragmatic discussion of the subject. It follows, then, that it is not recommendable to start with an element that lacks an informative value. And when both elements of Mubtada' (given) and Xabar (new) are definite 'you analyse as Mubtada' that constituent which in your assumption signals what is already known to the addressee, whereas what you assume to be unknown to the addressee you analyse as Xabar " (Ibn 'Usf̣ür, ibid,338). In summary, Mubtada' is considered as that which something is predicated of; and it is the element that talked and reported about. Such an understanding is originally existent in Sibawayh analysis of language as a social behaviour taking place in a defined context, where the role of both the speaker and the listener are essential in the success of speech communication (Baalbaki, 2008, 191-201). To conclude, the above discussion reveals, though partially, that the concept of thematic structure is existent within Arabic linguistic theory since its earlier years.

A further and more functional oriented approach was advanced by alJurjani's (d.1078CE) speech organization (النظم) (Ramunny, 1984, 361; Owens, 1988, 248-9; Kamel, 2002, 113; Peled, 2009, 123). These ideas of thematic structure, in general, merit a separate study from an SFL perspective. The above discussion on thematic - related issues, relevant to our old text, shed light on some important insights of 'functional' aspects. To what degree these aspects are functional is a different point that needs further studies. This study presents, as mentioned earlier, a partial interpretation of Arabic in SFL terms, and does not claim to offer a comprehensive treatment of SFL.

${ }^{11}$ Peled is commenting on Ibn Ya '־̌š analysis, and not on Ibn as-Sarraj. 


\section{RESULTS: ANALYSIS AND DISCUSSION}

The analysis produced here is based on ten āyahs ${ }^{12}$ (41-50), of Sūra 19 of the Qur'ān. It narrates a pericope of the story of Abraham, which is mentioned in different Sūras. The Sūra includes a short dialogue in which Abraham tried to persuade his father to follow his new non- idolatrous way of worshipping God.

Some points relevant to our analysis need to be mentioned before presenting the analysis. Though the āyah may consist of more than one clause, the analysis is carried out at the clause level only. As regard the logical relations, with the exception of projection, manifest in our text, their various aspects of interdependency (taxis) and logico-semantic (expansion) are not elaborated. In analysing the projection, its function, as one aspect of this relation, was given much more focus than its level, and mode. That is, our focus is to analyse thematic structure of the projected clause since it is that which develops the message. Secondly, in the exposition of the analysed text, Textual and Interpersonal Themes are underlined; whereas Topical Themes, consisting of the verbal group together with Subject as a free standing or a bound morpheme, are in bold. Due to Arabic orthography it is not possible to separate bound morphemes from its respective verbal group. In the English translation, only Topical Themes are in bold. Discussion will be limited to the different points related firstly to the thematization of the verbal group, and secondly, to the orientation of Theme in terms of how topical and/ or interpersonal meanings are organized. The analysis is for Arabic text only.

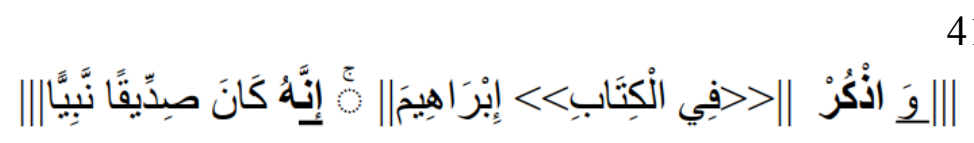

|| and mention in the Book Abraham || indeed he is a trustworthy, a prophet $\|$

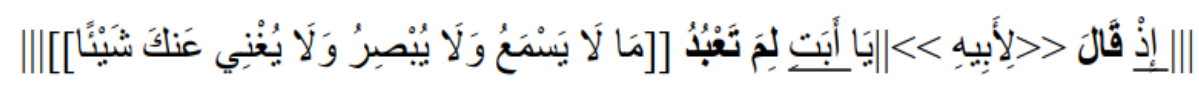

|| as said (he) to his father $\|$ O! Father why you worship [[that which neither hears, nor sees, nor avails you anything]] |||

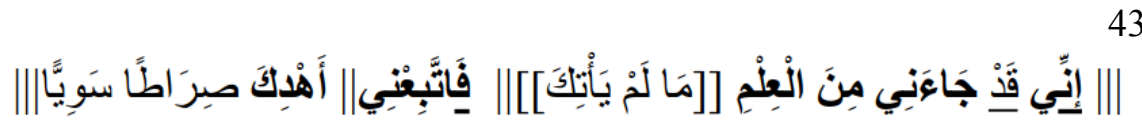

||O' My Father, I assure really came me of knowledge [[that which reached not to you]]|| follow me|| so that lead (I) you on the right path||

\footnotetext{
${ }^{12}$ I used Arabic words of āyah and Sūra to avoid confusion with biblical words of verse and chapter.
} 


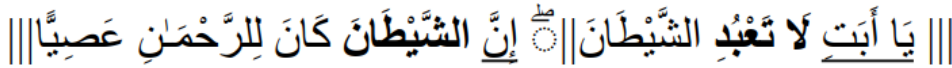

||O! My Father, do not worship the Satan $\|$ Satan is disobedient to the Merciful\|

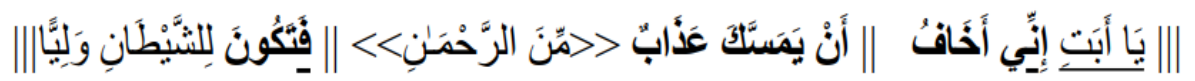

||O' My Father, I assure fear (I) that a punishment $<<$ from God $>>$ inflicts you\| so become (you) a friend of Satan|\|

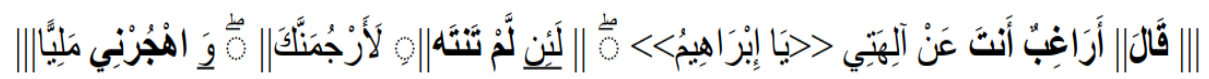

|| said (he) || rejecting you my gods $<<\mathrm{O}$ ! Abraham $>>$ ? || if do not desist (you) $\|$ stone (I) you $\|$ and leave me for ages $\|$

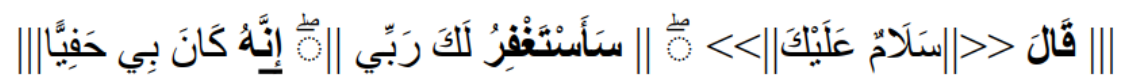

|| said (he) $<<\|$ peace on you $\|>>\mid$ will ask (I) my Lord to forgive you $\|$ he is indeed kind with me|||

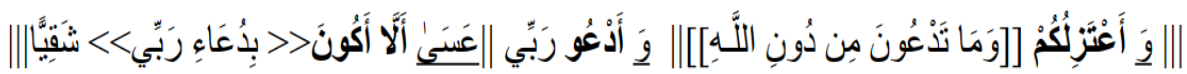

|| and withdraw (I) you[[and that unto which pray (you) instead of God]] $\mid$ and pray (I) unto my Lord\| perhaps not become (I) with my Lord pray unblessed |||

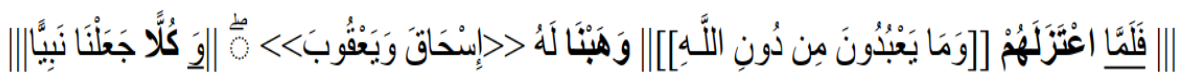

|| when abandoned (he) them[[and what worship(they) instead of God]]\| gave (we) him Isaac Jacob || and both made (we) prophet||

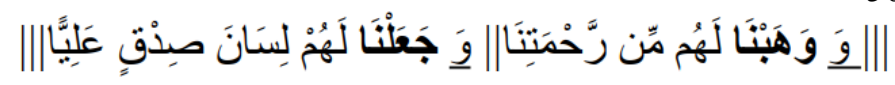

|| and gave (we) them of our mercy $\|$ and assigned (we) to them a high and true mention of eminence|||

Since the three metafunctions operate simultaneously, there is more than one Theme in the same place, i.e., topical, interpersonal and textual, as Table1 shows. The textual and interpersonal themes, that precede the topical Theme, play no part in the experiential meaning of the clause (Halliday and Matthiessen 2014, 107). Their function is restricted, in the case of the textual Theme, to structural and logical-semantic relations; whereas the interpersonal themes are related to speech functions expressed through modality. 
Table 1 number and percent of the multiple Themes

\begin{tabular}{|l|l|l|l|l|l|}
\hline \multicolumn{5}{|c|}{ Theme type : number \& \% percent } \\
\hline \multicolumn{2}{|c|}{} & \multicolumn{2}{|c|}{ Interpersonal } & \multicolumn{2}{l|}{ experiential } \\
\hline textual & percent & number & Percent & number & percent \\
\hline 11 & $23 \%$ & 11 & $23 \%$ & 25 & $53 \%$ \\
\hline
\end{tabular}

It suffices to give a brief account of textual and interpersonal themes; elaborating their logical relations is beyond the scope of this study. As for Textual Themes, the most frequent is 'wa'; it represents the most commonly coordinator used in Arabic, classical and Modern. Therefore, Arabic is described as a syndetic language (Holes 2004, 266-267; Ryding 2005,407). The structural meaning of 'wa' ('and'), as a coordinating conjunction, is what the grammarians mainly focused on. Interpersonal Themes, on the other hand, consist of 'inna (إنَّ), vocatives and modal operators (عسى ،سوف،قد in āyahs 43, 47, and 48, respectively). However, 'inna is the most common interpersonal element in this Qur'ānic narrative expressing meanings of general affirmation and emphasis beside others (as-Samarra'i 2000 v1:286; Versteegh 2006, v2, 354-358).

\subsection{Topical Theme}

The following discussion will cast light on the preeminent feature of thematic structure, i.e., thematization of verbal group; as well as other relevant points indicated below to give a more detailed picture of the importance of verbal group in Theme position.

\subsubsection{Thematizing of verbal group}

In the thematization of verbal group (Process), there are two noteworthy things. The first concerns the realization of the topical Theme; it is principally expressed by the verbal group (Process) amounting to $80.0 \%$ with 20 out of 25 (number of total clauses). The nominal group constitutes only $20.0 \%$ with only 5 instances (āyahs 41, 44, 46, 47 and 49. All are almost in the second clauses).

The second finding is related to the type of clauses, in terms of MOOD system. Declarative clauses constitute the majority; in second place come the imperative clauses, which are mentioned only four times (āyahs 41, 43, 44, and 46). And finally come interrogatives clauses, found in only two instances (āyahs 42, 46). The first is an elementary interrogative in āyah 42 that stands alone as a Theme; the other is a polar interrogative, present in āyah 46 that constitutes, together with the verbal group, the topical Theme.

It is important to note that Theme realization, in interrogative and imperative clauses, is similar to that of English in its general outline. Theme realization in declarative clauses, which is noticeable, shows some degree of 
variation. The majority of Themes are unmarked, with the exception of two instances. The first is in āyah $46^{13}$, and the other one is in āyah 49 (كُلاً as a complement).

But before we proceed to discuss these points, a mention of the types of Processes is necessary. These Themes, realized by Processes (verbal groups), have bearing on the message meanings, experientially and interpersonally. Apart from the 'saying' verbs- that set up a projection relation-, the rest were all located in projected clauses. Being Theme, the verbal group, in the projected clause, represents the local context and orienter of the message. This is because our analysis, as explained earlier, is centred on the projected clause that expresses the content of the projection, and hence its function. The prevalence of the Processes in Theme position takes us to discuss the point of conflation with predictor (as a component of the MOOD System) in the position of Theme (4.1.3 below).

Table 2 Types of processes

\begin{tabular}{|l|l|}
\hline Process type & $\%$ percent \\
\hline Material Process & $39.13 \%(\mathrm{n} .9)$ \\
\hline Verbal Process & $26.08 \%(\mathrm{n} .6)$ \\
\hline Relational process & $21.05 \%(\mathrm{n} .4)$ \\
\hline Mental Process & $4.34 \%(\mathrm{n} .1)$ \\
\hline
\end{tabular}

4.1.1.1 First person pronoun bound to Interpersonal Theme: Extended Theme region with a subjective view

Of importance in declarative clauses is the thematic structure shown by the ayah 43 (Table 4), taking it as an example for similar cases. This structure pertains to first person pronoun singular (in the accusative case) bound to the particle 'inna (إنّ) (in the interpersonal Theme region). This particle is among a group of particles known in Arabic grammar as 'inna and its sisters; they are also known as verb-like particles. 'inna (إنّ), which is highly frequent in the Qur'ān, normally precedes the nominal clause (i.e., consisting of only nominal parts) and expresses the general meaning of confirmation (I confirm, I assure)

\footnotetext{
${ }^{13}$ Its markedness is based on the notion of foregrounding in that it highlights the prominence and the attention given to his father rejection to Abraham's call (Ibn 'Ašur, 1983, v.16, 118119). Arab grammarians consider it as a fronted Xabar whose Mubtada'? is the explicit pronoun (you) coming after (ibid). Structurally it is an active participant that occurs as Xabar (Rheme) in the Qur'ān (to cite but a few 2:30, 41, 89,124,145; 18:6; 65:3). The active participle is a subtype of noun lacking agent marker, but replicates many properties of a verb, and since it has no inherent tense, it must be contextualized to represent a tense (Owens and Yavrumyan, 2006, v3, 542). Its occurrence is abundant in the Qur'ān.
} 
(Ibn al-Xašab1972 [d.1171 CE],69; Barakat, 2007, V1,172-173). ${ }^{14}$ This meaning becomes very apparent when it is bound to a first person pronoun, thus conferring a more subjective orientation on the speaker/writer in Theme position. Looked at from an SFL perspective, 'inna (إن) somewhat resembles the function of interpersonal projection in hypotactic projecting clauses (in English) as the following table shows (Thompson, 2013,169), in which 'I think' represents the interpersonal Theme, and 'those days' stands for experiential Theme (ibid).

Table 3: interpersonal and topical Themes (Reproduced from Thompson 2013, 169)

\begin{tabular}{|l|l|l|}
\hline $\begin{array}{l}\text { I think } \\
\text { I suspect }\end{array}$ & $\begin{array}{l}\text { those days } \\
\text { the clocks } \\
\text { John Hamm }\end{array}$ & $\begin{array}{l}\text { are gone } \\
\text { might have been replaced. } \\
\text { is too old to be Batman, I think. }\end{array}$ \\
\hline interpersonal & experiential (topical) & \\
\hline Theme & Rheme \\
\hline
\end{tabular}

Due to its interpersonal orientation, I call 'inna a subjective Theme to differentiate it from other various types of interpersonal Themes. ${ }^{15}$ Thompson $(2013,168)$ holds that these "Interpersonal meanings are experientialized and treated as if they were 'content' meanings". He states that they can be viewed from experiential angle which takes wording as primary as well as from interpersonal angle that gives function a pre-eminence in terms of modal or evaluative meaning (ibid,169). The point I am trying to show here is that this occurrence extends the topical Theme region in that we get two, let us say, thematic regions, one expressing subjective Theme orientation, and the other having the Subject/Theme in it. In this specific example (Table 4), the first person singular bound to the particle (إنَّ) 'inna provides the subjective interpersonal view of Theme. This functional aspect of the pronoun is based on considering this pronoun, though it is structurally in the accusative case, as standing for 'I', occupying a place of a Theme and conflating with the Subject. Otherwise explained, the first person pronoun singular, though bound to the particle of 'inna- an interpersonal Theme- actually has the power of

\footnotetext{
${ }^{14}$ Beside confirmation, it has other meanings of conjunction, and explication (giving causes) (as-Samarra' ì, 2000, V1, 286-293). There are some disagreements about the scope of 'inna in expressing confirmation; whether this is the whole clause or only the Xabar (Rheme). Further analysis is needed to better understand the semantic function of 'inna in thematic position. Generally speaking, they bear formal and semantic resemblance to verb meaning. For example, 'inna (إنّ) expresses the meaning of 'confirm' and 'assure' verbs; when connected to first pronominal pronouns, they could be rendered as follows: I confirm, and I assure. Further analysis of their semantic aspects is needed to better understand its position in thematic position (cf. Versteegh, K., 2006, 355-8).

15 That is, modal Adjuncts and modal operators.
} 
being a Theme on its own in the same manner its free standing equivalent 'I' in the theme position does, irrespective of their syntactic features; however, its binding to 'inna confers a thematized subjective orientation to the message. This of course extends and broaden thematic region; however, it is different from the case we are going to elaborate later in the section 4.1.3, which concerns the extension of topical Theme boundary to include both the verbal group and the Subject implicitly existent, in the form of pronominal markers, in Arabic verbal groups.

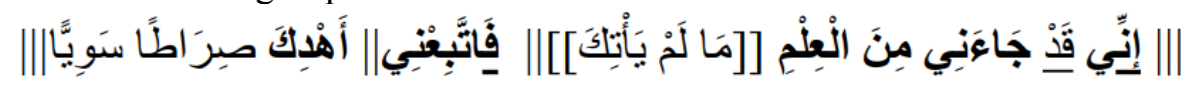

Table 4: extended Themes in āyah 43

\begin{tabular}{|l|l|c|}
\hline I assure [you] & $\begin{array}{l}\text { Came [A kind] of } \\
\text { knowledge }\end{array}$ & to me [[that which reached not to you]] \\
\hline Interpersonal Theme & Topical Theme /Subject & \multirow{2}{*}{ Rheme } \\
\hline \multicolumn{2}{|c|}{ Extended Theme } & \\
\hline
\end{tabular}

The topical Theme, in this case, consists of the verbal group ("came' ${ }^{16}$ ) plus the (grammatical) Subject (of knowledge). The Subject realized by the prepositional phrase 'of knowledge' is the warranty of a transaction exchange between speaker and listener in that "it is the element the speaker makes responsible for the validity of what he is saying" (Halliday and Matthiessen 2014,83), and it that holds the responsibility "for the functioning of the clause as an interactive event" (ibid, 146). Again this, of course, is different from extending the boundary of Theme to cover two experiential elements (Process and Participant).

\subsubsection{Projection and ellipsis of projecting clause}

The third finding is the presence of the projection relation, in particular, the verbal-locution- type, and it is relevant to give a brief account of projection. Projection in simple terms means that we use language to talk about language (Thompson 2013, 201). That is, the use we make, in our message, of the wording (i.e., quote) or the meaning (i.e., report) of the original language event is not a representation of '(non-linguistic) experience' rather a 'representation of a (linguistic) representation' (Halliday and Matthiessen 2014, 508). The projection consists of the projecting clause (the source of the wording of a verbal clause- or the meaning of a mental clause) and the projected clause (content of that wording or meaning). The prevalent type here is the verbal-locution- projection realized by a 'saying' verb, in

\footnotetext{
${ }^{16}$ Interestingly enough this Process seems to be a Material Process; exegeses consider it as a Relational in the sense 'I have with me some kind of knowledge' (see for example, Ibn 'Ašur, 1984, v16, 115).
} 
which the projected paratactic quote does not need to fit in with the projecting clause in Mood, reference, register, dialect, etc. (Thompson 2013, 202).

In our text, the locution projection is mentioned in the beginning of four āyahs (41, 42, 46 and 47). In each of these instances, the projecting clause (said-he) serves to provide the source of the information in that it indicates that Abraham is the speaker in āyahs 42-45; and also in ayahs 47-48; while in ayah 46 , it is his father. Finally, there is one mental projection located in the projected clause of āyah 45 ('I fear that a punishment from God inflicts you'). In this regard, two noteworthy points need clarification. First, as explained earlier, our focus is not the projection relation; therefore its function, the important part of this relation, which is expressed in terms of proposal and proposition (declarative, interrogative, and imperative), will be discussed implicitly within the Theme function (orientation) in section 4.2. Secondly, as the projecting clause (said-he) was not repeated in the clause complexes of ayyahs $43-45$, or in āyah 48 , these clauses are taken as continuation of projection where only the projected clause is mentioned. In other words, the projecting clause (said-he) was dropped; and such a dropping is common in the Qur' ānic narratives. ${ }^{17}$

\subsubsection{Conflation of Theme with predicator}

We can explain the conflation of Theme in verb-initial declarative clauses with Predicator (in Mood system) in the light of types of clauses in Arabic. Apart from the nominal clause that consists of only two nominal groups, the clause (sentence) in Arabic is classified into verbal or nominal according to the first element with which it starts. It is nominal if it starts with a noun (SV) and verbal if it is verb initial (VS) ${ }^{18}$. This classification represents the view of the Basra School; however, according to the Kufa School, both of these types are verbal clauses since a verb exists in each of them irrespective of its position in the sentence, i.e., pre or post-noun (al-Maxzumi 1974, 31-47). It is worth mentioning here an oft- repeated argument that Arabic is a 'verb-initial' language where the VSO or VOS structures represents the 'normal' or 'basic' word order from which other configurations are derived ('Abdul-Raof 1998,44). But there is nothing in the traditional linguistic writings supporting such a claim ${ }^{19}$ (Peled 2009, 30), which also lacks corpus-based findings (as-

\footnotetext{
17 To cite but a few, Q 2:36, 92,125,127,285; Q 3:79,191; Q 6: 93,104,128; Q13:23-24.

18 This a very general description of sentence types in Arabic as viewed by grammarians; rhetoricians' criteria are functionally based (some prefer to call it pragmatic), dividing it into two divisions: reporting (خبرية) and informing (انثائية) (questions, commands, wishes, exclamations, oaths, conjunctions and contractual declarations). This topic has received a wide discussion in contemporary literature on Arabic linguistic tradition.

${ }^{19}$ Peled here argues against 'Abdul-Raof claim that "Written Arabic as basically a "VSO language", from which other configurations are derived, is advanced by "classical"
} 
Samarra'i 1983, 206). Rather, Arabic has a free and flexible word order permitting different configurations.

Theme boundary in verb-initial clause, therefore, should be explained in the light of the verbal inflection, which means that verbs carry the tense, number, and person and gender information (Beeston 1968, 39; Holes 2004, 179; Ryding 2005, 63). Our interest, however, is in the person system, of verbal inflection, that is represented by pronominal pronouns. Accordingly, the question raised here is about which part is Theme? Is it the verbal group alone or together with the pronominal morphemes (standing for the Subject) it carries? In light of what had been explained (in section 2.3 above) on extending Theme range, we believe that Theme range in verb-initial clauses should cover two elements of the transitivity system, Process and Participant, in particular in cases where Subject is not mentioned as an explicit nominal group, but rather as a morpheme (i.e., part of the verb). This extension is based on the notion, mentioned above, that the verb is marked mainly by a pronominal Subject, in form of affixes and suffixes (Table 5.1 and Table 5.2), respectively. In other words, Subject is part of the verbal group in verb- initial clauses in the form of pronominal markers (bound affixes and suffixes). Hence, Theme, realized by the verbal group, is actually consists of two topical elements, the lexical part and the pronominal markers that represent the information (system) of tense, number, person and gender.

Table 5.1 Personal pronouns markers in present (imperfect) tense

\begin{tabular}{|c|c|c|c|c|c|}
\hline \multicolumn{2}{|c|}{$3^{\text {rd }}$ person } & \multicolumn{2}{|c|}{$2^{\text {nd }}$ person } & \multirow{2}{*}{$\begin{array}{l}1^{\text {st }} \text { person } \\
\text { s. }\end{array}$} & \multirow[b]{2}{*}{-1} \\
\hline m.s & ي- & m.s. & تَـــ & & \\
\hline f.s & -3 & f.s. & تَ بِينَ & p. & نَـــ \\
\hline m.d & يَ عَانِ & d. & تَ كانِ & & \\
\hline f.d & تـ كانِ & m.p. & تَتُونَ & & \\
\hline m.p & يَـونونَ & f.p. & تَنْنَ & & \\
\hline f.p. & يَنْنَ & & & & \\
\hline
\end{tabular}

Table 5.2 Personal pronouns markers in past (perfect) tense

\begin{tabular}{|c|c|c|c|c|c|}
\hline \multicolumn{2}{|c|}{$3^{\text {rd }}$ person } & \multicolumn{2}{|c|}{$2^{\text {nd }}$ person } & \multirow{2}{*}{$\begin{array}{l}1^{\text {st }} \text { person } \\
\text { s. }\end{array}$} & \multirow[b]{2}{*}{ تُ } \\
\hline m.s & $=$ & m.s. & 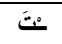 & & \\
\hline f.s & ت- & f.s. & تْ & p. & هنَا \\
\hline $\mathrm{m} \cdot \mathrm{d}$ & L & d. & 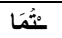 & & \\
\hline f.d & 更 & m.p. & 苑 & & \\
\hline m.p & - & f.p. & مَنَّنُ & & \\
\hline f.p. & نَن & & & & \\
\hline
\end{tabular}

grammarians. Peled asserts that he "have found no evidence in the medieval grammarians' writings that bears this out" $(2009,30)$. 
This implies that these pronominal markers substitute the free standing pronouns as Subject. The Subject ${ }^{20}$ is still present in the verbal group, and through which the thematic progression could be traced, as well as setting up the referential relation. It follows then that since verbs in VS clauses carry pronominal markers, these markers, representing Subject, should be included within the Theme range together with the verb. In Spanish, a similar situation, regarding Theme in verb-initial clauses, had been debated. Some scholars opted to take these pronominal markers (Subject) within Theme boundary (Lavid et al 2010:299-306; Lavid and Moratón 2015, 295). The explanation they proposed, briefly presented here, states that the thematic Field consists of two regions: preHead carrying the verbal group, and the Thematic Head representing the bound pronominal markers (as Subject). These bound pronouns (the morphemes of -ó, and -a), Table 6 and 7, respectively, represent the first experiential elements, and together with the verbs they form Thematic Field (examples taken from Lavid and Moratón 2015, 295).

Table 6 Pronominal Subject (morpheme) in the theme position in past tense

\begin{tabular}{|l|c|c|}
\multicolumn{2}{l}{$\begin{array}{l}\text { Pronto } \\
\text { Soon }\end{array}$} & $\begin{array}{l}\text { comprendió } \\
\text { UNDERSTAND- 3psg Past the truth }\end{array}$ \\
\hline Pronto comprendi- & Ó & la verdad \\
\hline PreHead & Thematic Head & Rhematic Field \\
\hline Thematic Field & & \\
\hline
\end{tabular}

Se halla ahora ante un nuevo ataque cibernético

'it is now facing a new cybernetic attack'

Table 7 Pronominal Subject (morpheme) in the theme position in present tense

\begin{tabular}{|l|l|l|l|}
\hline se & hall- & $-a$ & $\begin{array}{l}\text { ahora ante un nuevo ataque } \\
\text { cibernético }\end{array}$ \\
\hline Pron.'se' & Find & 3psg. Pres. Ind. & \\
\cline { 1 - 2 } PreHead & Head & Rhematic Field \\
\hline \multicolumn{2}{|l|}{ Thematic Field } &
\end{tabular}

In this model, it is the pronominal morpheme that constitutes the first topical element taken as Theme; however, in our analysis we include both of the verbal group and its pronominal pronoun as Theme because bound

\footnotetext{
${ }^{20}$ Subject is understood in the sense of being modally responsible. 'Abdul -Raof, $(1998,119)$ holds that the Arab grammarians failed to differentiate between the semantic implications of the three different types of subjects (psychological-theme, grammatical, and logical-doer of action). I will show in 4.1 .5 that they touched on such concepts in passing when they discussed the resemblance between Mubtada' and Subject on the grounds of the predicative relation.
} 
pronouns (as well as the implicitly carried pronouns by the verbal group) cannot be presented separately.

Finally, this problem of Theme boundary is more evident and controversial in translation studies between English and languages like Spanish and Arabic where the Subject forms implicitly a part of the verbal group. For example, Munday $(2000,42)$ argued for including these pronominal pronouns of Spanish verbal clause in Theme, when translating from Spanish into English. More importantly, some studies that examined thematic structure in Arabic and its corresponding English translations, adopted a similar analysis. We cite just two cases. Al-Jarudy $(2011,127)$ argued that verbs (on their own) as unmarked Themes in Arabic are unable to carry out a comparative analysis of Theme and Rheme in English and Arabic news reports; therefore the explicit Subject in the form of nominal group should form a part of Theme. Obiedat $^{21}(1994,399)$, in his analysis of translation between Arabic and English, however, took only the explicit Subject (nominal group) in VSO clause type as Theme. Baker $(1992,127)$ had already pointed out that analysing verb-initial clause in accord to Halliday's model "may not be as workable as it is in English" because the effect of placing inflected verbs in Theme position is not the same as in English even though they carry "the same information as an English pronoun-plus-verb combination". For example, in using verbs inflected for first person pronoun "it is difficult to discern a theme line as clearly as in the pronoun-plus-verb combination". And the impact of a series of these verbs is not the same as "the impact of series of I's in Theme position" (ibid).

\subsubsection{Resemblance of Verb to Xabar in the predicative relation}

We would like to bring to the fore an idea, touched on in the Arabic grammatical tradition, that relates to a resemblance between subject in VS clauses and Mubtada' in Mubtada'-Xabar structures. This resemblance bears relevance to the verb function in verb-initial clauses, interpreted within the predicative structure of Subject-Predicate. The argument goes as follows: subject in VS clauses resembles the Mubtada' (initially positioned), in Mubtada'-Xabar structures, on the grounds that they are reported of and talked about. In other words, a verb initially positioned (in a VS clause) resembles the Xabar (second part of Mubtada'-Xabar structure) in that their function, as new information, is to predicate of, and report about, something else (subject and Mubtada', respectively) (Ibn as-Sarraj [d.928 CE], 1996 v1, $58,72-75)$. The difference, however, is that the Mubtada' is initially positioned, whereas the subject comes after the verb (initially positioned and occupying the function of a predicate). Ibn as-Sarraj makes explicit the

21 'Obiedat (1994) gives a wide of SFL-based analysis of thematic structures in Arabic (chapter 5). 
difference in this way: 'do you not see if you said 'زيُّ منطلق', (Zaid [is] departing) you started with Zaid of whose departure you inform (i.e., Xabar), which comes after it; whereas if you say: بنطّ زيُّ departs Zaid' [Zaid departs], you start with the new information (departure), then you mentioned Zaid, whom the departure process informs about. Thus the verb represents the new information though it is fronted (initially positioned). This means that the verb (initially positioned in VS clause) performs the function of Xabar (Rheme) that needs to predicate of, and talk about, another thing (Theme) (Ibn Ya ${ }^{\prime} \check{1}$ s [d.1246 CE], 2001 v1, 73). ${ }^{22}$ In other words, the verb cannot be predicated of because it represents a Xabar (Rheme), and if you predicated it to another verb, you will not benefit the addressee because the communicative value of speech is realized only by a verb that predicates of a talked about noun (Theme) as in 'stood Zaid' [Zaid stood] (قَامَ زيدّ) and 'sat down Bakr' [Bakr sat down] (قَعَدَ بكرُ " predicate whose function is to inform of another thing else. If it is definite, it loses its function of being the new information the listener needs to know (about the Mubtada'). That is, because you start the speech with a noun known to both you and the addressee, then you provide that which the addressee does not know (ibid, 86).

Two important points, we believe, from this passing review can be drawn. The first is that the predicative relation establishes that the subject is understood as a (grammatical) Subject on which the value of this relation depends since it is the Xabar, though initially positioned, takes the job of informing about the Subject, which is responsible for the validity of the proposition of the clause as understood in SFL. In other words, the grammarians interpretation of equating Subject to initially positioned element (i.e., Theme), actually represents the (grammatical) Subject because it was elaborated within the predicative relation (of Mubtada'-Xabar) of being the predicated of and talked about element in this relation. Secondly, it also suggests that verb (in VS clause) using SFL terms, is marked since it is fronted, even though it is interpreted structurally of being the 'operator' that acts on the subject to give it its nominative (independent) case. The semantic resemblance between 'Mubtada' (topic/subject) and fai'l (agent/subject) is evident in that about each of these constituents something else is reported" (Versteegh 2007, 434-437). Actually, more and profound functionally based

\footnotetext{
${ }^{22}$ Weiss $(1985,612)$, in discussing the inscriptive linkage between subject-predicate, interprets Arab philologists' distinction between nominal and verbal sentences on the ground that they notices that a verb may function only as a predicate-expression (of a verbal sentence) as compared to the noun. And this is because "the verb did not seem to be able to function semantically except when joined to subject-expression" because "it displays a certain kind of incompleteness which did not seem to characterize the noun".
} 
analysis is called for to elucidate the verbal group significance in Theme position. ${ }^{23}$

As a conclusion to Theme related points in Arabic, it is convenient to mention what Halliday had already pointed out about universal features of language. He stated that "while all languages are assumed to have a "textual" component, whereby discourse achieves a texture that relates it to its environment, it is not assumed that in any given language one of the ways of achieving texture will be by means of a thematic system. Even if there is such a system, the features in it (the choices) may not be the same; and even if a feature embodies the same choice, it may not be realized in the same way. There might be a thematic system, but one which is not based on the principal of an unmarked choice for each mood; or there might be such a choice, but not realized by the order in which elements occurs [.....]" (Halliday 2000/1994, F60).

\subsection{Theme orientation and its semantic implications}

Now we come to explain the semantic aspect of the Theme, that is- its role and function in terms of how it contributes to the unfolding and development of the message so as to guide and help the addressee's understanding and processing of it. This is generally known as Theme orientation in that the linguistic resources of the topical and interpersonal metafunctions, through Theme-Rheme structure, are organized to produce text. That is to say that in Theme both meanings are combined and woven in such a way to influence message unfolding towards one or other meaning. In other words, it is the function of Theme to display which meaning, of these two metafunctions, is prominent in unfolding the message. It follows that meanings of the reality and the choices of interpersonal interactions cannot be understood or carried over without being set in a message. Finally, the "weaving" of these meanings

${ }^{23}$ A passing allusion to the notion of a (grammatical) Subject is made by Ibn Jinnī (alXasă is 1952 v1.184-185), in his reply to those who see the weakness of the grammarian's justification of noun case-endings. Ibn Jinnī cites the critics' argument as follows: "grammarians say that the subject (actor) has a nominative case and the direct object an accusative case; though we find instances run against this rule. For example, did not you see that we say (ضُربَ زيدّ) "Zayd was hit" assigning to Zayd a nominative case even though Zayd is a direct object? And we say (إنَّ زيداً قائزّ) "indeed Zayd stood up" assigning to Zayd an accusative

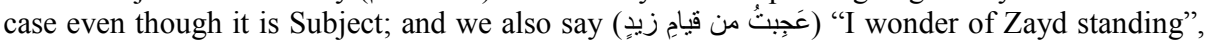
assigning to Zayd a genitive case though it is Subject. Such a criticism is nonsense, Ibn Jinnī replied; and he added that if the questioner - the critic- had known that Subject, as understood by grammarians, is not that which is semantically Subject (فاعل معنوي) (literary, subject in meaning), rather it is the noun that which comes after a verb and you predicated that verb of that noun, his disquiet would fall away and vanish". The point I am making here is that Subject in these examples corresponds to the (grammatical) Subject as understood in SFL in that it is the element that "is being held responsible for the functioning of the clause as interactive event" (Halliday \& Matthiessen 2014,146). . 
together with the textual structure is that which produces a coherent whole (text) (Halliday 1971, 95).

To illustrate how Theme combines these two meanings (content and interaction), different types of imperative and indicative (declarative and interrogative) clauses are given below.

\section{-Imperative clauses}

In ayah 44, the Theme, 'don't worship', consists of both the 'no' particle and the process. It is a negative imperative that represents the ideational content. And this ideational content (material process: a doing) construes the speaker's experience of his world (the religious belief of monotheism) that can be talked about. The interpersonal function of the same Theme is expressed by a command issued by Abraham, as a speaker, to his father, as an addressee; and this function "defines the specific communication roles the speaker has chosen for himself and for the listener" (ibid). Thus in simple terms, Theme is a pot in which both ideational and interpersonal meanings are melted. However, the total structure of Theme-Rheme is that which conveys the semantic significance.

Another example of imperative Theme is āyah 43, the second clause 'then follow me', in which we notice the same combination of content (ideational) and interaction (personal) meanings. It first illustrates the ideational system (material process: transitivity system) in which the speaker (Abraham) construed his experience of the world based on his possession of a kind of knowledge (first clause) that entitles him to know the right way. Secondly, the Theme (follow me) sets up the interpersonal relation of a command (speech functions: imperative) that puts Abraham on the upper hand to direct his father attitude by issuing this order. In other words, this personal interaction shows relation of knowledge-based power between the son and father.

\section{-Interrogative clauses}

In the first instance (āyah 42), the Theme is realized by the 'why', an elementary interrogative. The 'why', a 'circumstantial' element (in the transitivity system), construes the 'reason' of the 'doing' (material process of 'worshipping' idols), the speaker is talking about. In other words, the circumstantial element expresses language as content (the ideational function) the speaker derived from his experience of the world about the futility of polytheism. As to the personal interaction (interpersonal function), the 'why', part of mood system, expresses the interactive exchange of meaning in which Abraham, as a questioner, asking for information from his father, as an addressee, about worshipping the idols? It is worth noting that the idols are exophorically referred to as "that which neither hear, nor see and no avail anything". The second example is in ayah 46 (the first projected clause). Its 
Theme consists of both the polar particle (hamza) and the idiomatic active participle (expressing 'participant' in the transitivity system). This Qur'ānic use, of interrogative, here does not ask for yes/no reply, but rather it is a denial question (Ibn 'Ašur, 1983,v.16,118-119) in that Abraham's father denies that deserting his gods had dominated and took over Abraham thinking; and wondering how is it possible for Abraham to defy his father doctrine. And this is the ideational component of the Theme. The Theme from the interpersonal function is a proposition that sets up the father attitude of denying, and rejecting his son behaviour.

\section{-Declarative clauses}

The ayah 47(the second projected clause) demonstrates this type of Theme: "I will ask for forgiveness [for you from my Lord]". The ideational (content), a 'process' (in the transitivity system), construes Abraham experience of negotiation with his father's old belief system. And as Abraham perceived the futility of keeping arguing with his father, he preferred to soften his tone and took a respite. The personal relation (interpersonal function) is construed through an offer (modulation) Abraham made to ask for forgiveness from his lord (i.e., Abraham's Lord) for his father. It expresses the affectionate son-father relationship in which Abraham, as a son, implores his Lord for the benefit of his father, and to maintain this relation, despite the religious faith conflict.

Having illustrated the meaning of Theme of being the element of textual system where both meanings of ideational and interpersonal systems are woven, we proceed to show the degree to which the text is experientially (ideational content) or interpersonally (personal interaction) oriented. In other words, what are the elements that can display Theme, as a local context for unfolding the message, orientation towards ideational or interpersonal meanings? This is what we are showing in the following account.

Given that the dialogue, in this pericope, runs along the whole text and is carried out by propositions and proposals (speech functions) between two participants (speaker and addressee), Theme as a point of departure is expected to develop an interpersonal orientation in the message unfolding; and this is realized through various ways, of which some will be discussed below without assigning any priority or importance of order since all collectively contribute to reveal this orientation.

\subsubsection{The projection}

In general terms, the projection serves as a frame through which these interpersonal meanings are displayed, by virtue of using the speech denoting verb in particular, 'saying' verbs. As noted in the results the verbal (locution) projection, realized by the 'say' verb in the past tense, is manifest in this 
pericope, covering the āyahs 42-45; 46 and 47-48. its paratactic mode (quoting), frequent in this narrative text, establishes in the dialogue a level of interaction between the parties involved; and this interaction is realized by the speech functions which is particularly "associated with certain narrative registers, fictional" (Halliday, 2000/1994 256). As the dialogue in a paratactic projection allows for wide range of speech functions to be expressed, the interpersonal meanings will be noticeable and brought to the fore. And this is done through the moves of the exchange or the dialogue (Thompson 2013, 202). In other words, the interpersonal interaction is expressed through speech functions of giving and demanding information and goods-\& services. For example, asking a question or commanding an order by one party, in a dialogue, requires a response from the other party. Thus the encoding of interpersonal meanings is enabled by the project relation. Forey $(2002,187)$ showed in his results a support for this trend; also he cited to the effect various works that back this finding (ibid, 179-180).

It is worth mentioning that the quoted (paratactic) projection produces the effect of being "more immediate and lifelike" (Halliday 1994,256), in that its elements of tenses, pronouns and others "are orientated towards the speech situation, while in reported speech they shift away from it"(Downing 2006,300), because of the independent status the projected element has (Halliday 1994,256).

\subsubsection{Thematization of modality}

Basically, the thematization of modality means that Themes express either meanings of modalization (statements and questions to realize meaning of certainty, affirmation, probability and usuality) and / or meanings of modulation (offer and command to explain roles of giving and demanding in terms of obligation, command, inclination and determination). Generally speaking, the thematization of modality, i.e., the thematization of first and second person pronouns invites interaction (Gerot and Wignell 1995, 83; Graber, 2001, 133; Eggins, 2004, 321) in such a way that interpersonal meanings in Theme position get prominence and orient the unfolding of the message. This is because one of the ways "the interpersonal meanings are realized" is "by expression of modality that may recur throughout the clause" (Halliday and Matthiessen, 2014, 387). And where there is a high degree of interpersonal interaction, message takes interpersonal meanings as point of departure (Graber, 2001, 133). These both meanings of modality are present in this pericope. For example, modalization is expressed by Theme of ayah 43 , in the first clause, expressing certainty, and in ayah 45 it expresses probability (expectation). On the other hand, modulation is used in ayyah 46 (first projected clause) expressing determination, and also in the second clause of the same ayah expressing inclination, and command-demand, and in āyah 47 it -modulation- expresses inclination (of willingness). In āyah 48, we 
notice a modulation (request). This use of thematization of modality increases and accumulates the interpersonal orientation in that "ideational meanings are built up in support of interpersonal orientation" (Matthiessen, 1995, 29).

\subsubsection{Alternation of personal pronouns: first and second person}

This element is interlinked with the previous one; it refers to the use of personal pronouns, in particular those bound with the verbal group in Theme position, which expresses the interpersonal meanings (of Theme). These pronouns are 'embodied in the person system, both as pronouns and as possessive determiners' (Halliday and Matthiessen, 2014, 387). Such use reveals the attitudes and behaviour, views and beliefs of the participants as well as the relationship. The whole passage showed the alternation of using first and second person pronouns, bound to the verbal groups (processes), between Abraham and his father. To give a rough picture, we note that in the whole dialogue that Abraham as a first person was mentioned ten times; his father was only two times. As a second person pronoun, Abraham was referred to four times plus his proper name; whereas his father was referred to eight times. It is important to point out that Abraham's share of the dialogue covers bigger space than his father, noticeable in the logical relations, expansion type, between the clauses in (āyahs 43, 44, 45, and 47). In other words, Abraham part of dialogue is more developed in that elements of dialogue are well-presented in terms of the negotiation (interaction) which contributed to the prominence of interpersonal meanings of Theme. A related point, expressed in experiential terms, is that Abraham carefully and meticulously exposed his viewpoints of both external and internal worlds; the former is reflected in his belief of the futility of idols worship-polytheism; whereas the latter is reflected in his receiving a kind of a knowledge from god, his ability to guide, his fear-expectation- of a punishment inflicts his father, his relation with his Lord (āyahs expressed in 43, 45, 47, 48, respectively). In other words, his internal world experience shows him as a responsible and affectionate carrier and giver of a message to carry out. It follows that Abraham's horizon is more dynamic in that the expression of his two worlds (external and internal) is so varied that enriched the dialogue evident in the processes used in constructing the narrative and carrying out the dialogue that covered meanings of advice, warning, exhortation, and sometimes a subtle command couched in a rhetorical style of argumentation and persuasion to serve his mission. His father experience, on the contrary, is limited in that he is rigid in defending his belief system (through denial, threatening and repudiating) where there is no place for negotiation (ayah 46). The level of interaction and status, and power between the two participants reflect the essence of interpersonal meanings. 


\subsubsection{Contribution of Interpersonal Themes}

The use of interpersonal Themes, preceding the topical Theme, has contributed to the prominence of interpersonal meanings. These interpersonal

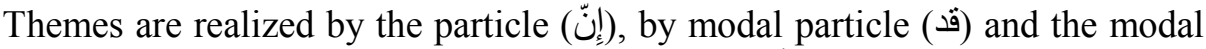
lexical verb (عسى), and finally the vocative (باأبت express meaning of confirmation, whereas the third one expresses meanings of hope and expectation. As regards the vocative, it lends a significant interpersonal charge since it refers directly to the addressee. The contribution of the formula of vocative, used in this pericope, to the interpersonal meaning of Theme is so evident. That is to say, the phrase (باأبت (ي) mentioned four times (āyahs 42-45), expresses, on the one hand, a very subtle, elegant and respectful way of addressing; it actually carries an emotional charge that helps backing the addresser position in such a situation of arguing, beseeching, and imploring. And it reflects, on the other hand, the relation of power and status between father and son in a patriarchal society. And this backed and provided an accumulation of interpersonally charged elements that guided the messages. It follows that Theme is interpersonally staged to develop the message through employing devices pertinent to such function. It stands to reason that interpersonal meanings, organized by textual metafunction, shaped the message development through the interpersonal interaction of a live dialogue between father and son. It should be noted that these elements are working together in weaving and expressing the interpersonal orientation of the Theme; the separate mention of them is to show how each can contribute to the realization of such an orientation.

\subsection{Cohesion ties: reference and ellipsis}

Thematic structure represents one system of resources of textual metafunction, realized principally at the level of the clause. There is another system- the system of cohesion (nonstructural resource) that transcends the boundaries of the clause and shows the other resources (lexico-grammatical) contribution to the textual meanings as a whole.

For the role the cohesion plays in this narrative (as a text), it is relevant to give a brief account of how Reference and Ellipsis, two cohesive devices, contributed to the cohesion of the text. Regarding the reference, its role in creating links between text parts is essential in holding together the different parts of the text. And this is noticeable from the first ayyah as it relates one element (Abraham as a participant) along the whole text. That is, it started from the very beginning of the narrative to its end. In this regard, Abraham represents a hyper Theme, about which the whole text revolves, important for the text unfolding. The second participant that has a referential relation is his father. 
It is worth mentioning that majority of the reference is endophoric established by the third person pronoun singular falling anaphorically on Abraham (āyahs 41, 42, 47, and 49: two times), and also on his father (āyah 46 falling back on 'his father' in ayah 42), which creates this referential relation on a relatively long distance in comparison to the short distance. The short distance reference is evident in āyah 47 , where the third person pronoun singular falls back on 'my lord' in the preceding clause of the same àyah; and also in the āyah 50, where the third person plural anaphorically falls back on Isaac and Jacob (āyah 49). Actually, reference plays an essential role in the cohesion of the Qur' ānic narratives and can be realized by different categories like demonstrative reference (Author, 2016), but in this passage it is mainly realized by person category. The exophoric reference, which is not cohesive, was mentioned in the ayahs $(42,48)$ contextually understood to refer to the idols; it also occurred in āyah 49, a third person pronoun plural (عنزلهم) referring to Abraham people understood also contextually.

The second cohesive element employed in this passage is ellipsis; it is "usually confined to closely contiguous passages, and is particularly characteristic of question + answer or similar 'adjacency pairs' in dialogue" (Halliday and Matthiessen, 2014, 606). It is confined in this passage to the process (verb), in a particular, that of the saying verb 'said (he)', in the projecting clause in a way that made the ayahs (43-45) appear as a continuation of projected clauses initiated by the projecting clause in āyah 42 . Also it is occurred in ayyah 48 which appeared as sequence of the previous one (āyah 47). It is worth noting that dropping this verb in the Qur'ān is common, as we explained earlier (footnote 17). The reference and ellipsis represent the grammatical devices of cohesion; as there is another kind of cohesion, realized by the choice of lexical items, called the lexical cohesion. One item of this cohesion is the repetition of Satan in ayyah 44; My Lord in āyah 48; and Father Mine four times in ayah 42-45. And this is not without a significant functional meaning. For example, in āyah 44 (in the second clause) the third person pronoun could have been used to refer to Satan, but the use of the explicit noun emphasizes the predicative relation in this clause, and also to deprive the human nature from Satan. The same applies to àyah 48, where the Lord is repeated twice instead of using the reference relation realized by third person pronoun (he). Finally, the conjunction when looked at as a system realized by elaboration, extension and enhancement is apparent but it is beyond our scope to give a detailed account of.

\section{CONCLUSIONS}

This study represents an endeavour to approach the Qur'ānic Arabic from an SFL perspective, which is almost untouched area, with the purpose of exposing the importance of the functional analysis in understanding the oldest text of Arabic. And because the textual metafunction organizes the linguistic 
resources used by the experiential and interpersonal meanings to produce the text, this research considers it as an essential step to start studying this variety of Arabic. Here we briefly mention the significant points this analysis showed:

-The use of multiple themes (textual, interpersonal and topical) with different importance attached to each kind in the message unfolding and the setting up of the logical-semantic relations between the text parts.

-Thematization of the verbal group influences Theme boundary in the declarative clauses. That is, to modify Theme boundary so as to cover two experiential elements (Process and Participant). And this expansion of Theme boundary recognition (view from below) is based on the inflection of the verbal group; because the verbal inflection expresses, beside other things, the person (Participant) realized by the pronominal markers bound to the verb. The presence of these markers helps track the Subject element in thematic progression. This modification (of Theme boundary) shows the importance of taking into consideration the characteristics of Arabic language rather than applying the language of the model (i.e., English).

- The majority of Themes are unmarked (realized by the verbal group), a point that has to do with maintaining the same topic about which the story revolves.

- The presence of the particle (إنّ) 'inna bound to the first person pronoun extends thematic region, conferring a subjective view on Theme. And this, of course, has bearing on Theme orientation to take more interpersonal meanings. And this orientation is carried out by the contribution of many elements.

-It is too early to claim that Theme is register specific; further and comprehensive studies on the Abraham stories (mentioned in different Sūras of the Qur'ān) in addition to other narratives across the Qur'ān, are needed.

-The Qur'ānic Arabic, in so far as the analysis of this narrative is concerned, lends itself to SFL. This does not mean that SFL is fully applicable to Arabic generally speaking; and it is relevant to avoid adapting Arabic language to the original model in English. What weighs here is actually the use of functionally based interpretation of language.

-Ideas and notions related to thematic structure are present in the Arabic Linguistic Tradition, though different from the SFL focus. Since our study is an exploration of the applicability of SFL tenets to Arabic, a profound investigating of Arabic grammatical tradition needs to be carried out.

\section{REFERENCES}

'Abdul-Raof, H. (1998). Subject, theme and Agent in Modern Standard Arabic. Richmond, Surrey: Curzon Press. 
Abu Zayd, H.N. (1995). An-naș wal Sulța wal Haqiqa. Moroco and Beirut: almarkaz ath-thaqāfī al-'arabī.

al-'Awādy, A. (2011). Siyāq l-ḥāl F̄̄ Kitāb Sibawayh. Jordan: Dār al-Hāmid. al-Jarudy, L. (2011). Ideological Representations in English and Arabic News Reports. PhD. Heriot-Watt University.

http://www.ros.hw.ac.uk/handle/10399/2459.

alJurjān̄̄, 'Abd al-Qāhir. (2000). Dalā'il al- 'i jā̃z. Cairo: Maktabat al-Xanchī. al-Maxzumi, M. (1986). Fī l-nahww al- 'arabī: Naqd wa-tawjīh. Beirut : Dār arRa'id al-'arabī.

Anghelescu, N. (2006). Theme/ Rheme. In eds. K. Versteegh, M. Eid, A. Elgibali, M. Woidich and A. Zaborski (Eds.) Encyclopaedia of Arabic Language and Linguistics.v.4 (PP. 484-487).Leiden \& Boston: Brill.

as-Samarra' ì, F. (2000). Ma 'aāni l-naḥw-vol1. 'Amman: Dār al-Fikr.

as-Samarra' '̀, I. (1983). al-fi'l zamānahu wa -bunyatahu. 3rd ed. Beirut :Mu'asassat ar-Rissala.

Baalbaki, R. (2008). The legacy of the Kitab. Leiden and Boston: Brill.

Badawi, El.d, Carter,M. \& Gully,A. (2016). Modern Written Arabic. A Comprehensive Grammar. $2^{\text {nd }}$ ed. Revised by Maher Awad. London \& NY: Routledge.

Baker, M. (1992). In Other Words: A Course book on Translation. London: Routledge.

Barakat, I. (2007). an-naḥw al- 'arabì. Voll Egypt: Dār an-Našr liljami aāt.

Beeston, A. F. L. (1968). Written Arabic. An approach to the basic structures. London \& N Y: Cambridge University Press.

Böwering, G. (2003). The Qur'ān as the Voice of God. Proceedings of the American Philosophical Society, 147(4), 347-353.

Butler, Ch. T. Miriam. (2008). Layering in structural-functional grammars. Linguistics 46(4): 689-956.

Btler,Ch (2003). Structure and Function: A Guide to Three Major structuralfunctional theories, v.1. Amsterdam \& Philadelphia: John Benjamins.

Carter, M. (2007). . Grammatical Tradition: History. In K. Versteegh , M.Eid, A. Elgibali, M. Woidich, A. Zaborski (Eds.), Encyclopedia of Arabic language \& Linguistics, v.2 (PP.182-191).Leiden/Boston :Brill.

Ditters, E. (1992). A formal approach to Arabic syntax: the noun phrase and the verb phrase.http://repository.ubn.ru.nl/handle/2066/114149.

Downing, A. (2006). English Grammar: A University Course. $2^{\text {nd }}$ ed. London \& NY: Routledge.

Fatani, A. (2006). "Language and the Quran. In O. Leaman (Ed.), The Qur'ān: an Encyclopaedia (PP.356-372). London: Routledge.

Fontaine, L., T.Bartlett and G. O'Grady (Eds) (2013). Systemic Functional Linguistics. Exploring Choice. NY: Cambridge University Press.

Forey, G. (2002). "Aspects of theme and their role in workplace texts. Unpublished Ph.D., http://theses.gla.ac.uk/5385/. 
Gerot,L. and P. Wignell.1995. Making sense of Functional Grammar. Queensland (Australia): Antipodean Educational Enterprises.

Goldenberg, G. (1988). Subject and predicate in Arab grammatical tradition. Zeitschrift der Deutschen Morgenländischen Gesellschaft, 138,39-73.

Graber, Ph. (2001). Context in Text: A Systemic Functional Analysis of the Parable of the Sower. www.isfla.org/Systemics/Print/Theses/PhilipGraberDiss.pdf

Graham, W. (1984). “The earliest Meaning of 'Qur'ān'. Die Welt des Islams, 23/24:361-377.

Günther, S. (2003). Literacy. In J. D. McAuliffe (Ed.) Encyclopedia of the Qur'àn, v. 3(PP. 188-192). Leiden /Boston: Brill.

Halliday, M.A.K \& C. Matthiessen. (2014). Introduction to Functional Grammar, $4^{\text {th }}$ ed. London: Routledge.

Halliday, M.A.K \& R. Hasan (1976). Cohesion in English. London: Longman.

Halliday, M.A.K. (1978). Language as Social Semiotic: The Social Interpretation of Language and Meaning. London: Arnold.

Halliday, M.A.K. (2000/1994). An Introduction to Functional Grammar, $2^{\text {nd }}$ ed. Beijing: Foreign Language Teaching and Research Press.

Halliday, M.K.A (2002/1971). Linguistic function and literary style: an inquiry into the language of William Golding' The Inheritors. In J. J. Webster (Ed.) Linguistic Studies of Text and Discourse, (PP.88-125), (v.2 the Collected Works of M. A. K Halliday). London/New York: Continuum.

Halliday, M.A.K (2007/1978). An Interpretation of the Functional Relationship between Language and Social Structure. In In J. J. Webster (Ed.). Language and Society, (PP.251-264), (v.10 the Collected Works of M. A. K Halliday). London/ New York: Continuum.

Hasan, R. and P. Fries (Eds.). (1995). On Subject and Theme: a discourse Functional Perspective. John Benjamins, Amsterdam Philadelphia.

Holes, C. (2004). Modern Arabic structure, function and varieties. Georgetown University Press, Washington.

Ibn al-Xašāb, 'Abū Muhammad 'Abdulla b. Aḥmad (1972). Al-murtajal Fi Šarh al-Jumal. Damascus.

Ibn as-Sarraj, 'Abū Bakr Muḥammad 1996. al-'Uṣūl fì l-naḥw-I. Beirut: Mu' assasat ar-Risāla.

Ibn 'Ašur, Muḥammad al-Ṭāher, (1984). Tafsir Attaḥrir wat Tanuir. adDār attunisiyah lilnašr.

Ibn Jinnī, 'Abū 1-Fatḥ 'Uțān Ibn Jinnī: al-Xasạ̄ iș. Ed. M. 'A. al-Najjār. 3 vols. Cairo: al-Hay'a 1-Mișriyya 1- 'Āmma li-1-Kitāb, 1986-1988.

Ibn 'Usfur, 'Alī b. Mu'min. (1998). Šarh Jumal az-Zajjājī-I. Beirut: Dār alKotob al-'ILmiyah.

Ibn Ya '̌š Muwaffaq al-Dīn (2001).Šarḥ al-mufașṣal-I. Beirut: Dār alKotob al'ILmiyah. 
Kamel, S.(2002). The textual components in Classical Arabic. Investigating information structure. In S. Boudelaa (Ed.), Perspectives on Arabic Linguistics: Papers from the Sixteenth Annual Symposium on Arabic Linguistics, v. 16(PP. 103-130). Cambridge: John Benjamins.

Lavid, J., \& Moratón,L. (2015). Intersubjective positioning and thematisation in English and Spanish: a contrastive analysis of letters to the editor. Nordic Journal of English Studies, 14(1), 289-319.

Lavid, J., J. Arús \& J. R. Zamorano - Mansilla. (2010). Systemic Functional Grammar of Spanish. London: Continuum.

Levin, A. (1981). The grammatical terms al-musnad, al-musnad ilayhi and al'isnād. Journal of the American Oriental Society, 101(2): 145-165.

Marogy, A. (2010). Kitāb Sibawayhi. Syntax and Pragmatics. Brill: Leiden/ Boston.

Matthiessen, C. (1992). Interpreting Textual Metafunction. In M. Davies \& L. Ravelli (Eds.), Advances in Systemic Linguistics: recent theory and practice: $37--82$ London \& NY: Pinter.

Matthiessen, C. (1995). THEME enabling resource ideational 'knowledge' construction. In M. Ghadessy (Ed.), Thematic development in English texts: 20-45. Pinter: London \& NY.

Montemayor-Borsinger, A. (2011). "theme" and "subject" in systemic functional linguistics: a discussion of thematic status. Cadernos de Linguagem e Sociedade, 12 (1):66-77.

Munday, J.( 2000). Using systemic functional linguistics as an aid to translation between Spanish and English: maintaining the thematic development of the ST. Revista Canaria de Estudios Ingleses, 40:37-58.

Neuwirth, A. (2006). Structure and the emergence of community. In A.Rippin (Ed.), he Blackwell companion to the Qur'ān: 140-158. London: Blackwell.

Neuwirth, A. (2007). Structural, linguistic and literary Features. In J.D. McAuliffe (Ed.), The Cambridge companion to the Qur'ann:97-113. Cambridge: Cambridge University press.

'Obiedat, N. (1994). The presentation of thematic structure in the translation of English and Arabic political discourse. Ph.D. Thesis. University of Durham.

Owens, J. M.Yavrumyan. 2006. "Participle. In K. Versteegh, M. Eid, A. Elgibali, M. Woidich and A. Zaborski (Eds.). Encyclopedia of Arabic Language and Linguistics .Volume2, (PP. 542-546). Leiden \& Boston: Brill.

Owens, J. (1988). The Foundations of Grammar. An Introduction to Medieval Grammatical Theory. Amsterdam/Philadelphia: John Benjamins.

Paret, R. (1983). "The Qur'ān-I. In A. F. L. Beeston, T. M. Johnstone, R. B.Serjeant, G.Rex Smith (Eds.), Arabic Literature to the End of the Umayyad Period,(PP.196-199). Cambridge: Cambridge University Press. 
Peled, Y. (2009). Sentence type Word Order Patterns in Written Arabic. Medieval and Modern Perspectives". Leiden Boston: Brill.

Rammuny, R. (1985). al-Jurjānī: a pioneer of grammatical and linguistic studies. Historiographia Linguistica 12(3), 351-371.

Ravelli, L.(1995). A Dynamic Perspective: Implications for Metafunctional Interaction and an Understanding of Theme. In R. Hasan, P. H. Fries (Eds.), On Subject and Theme,(PP. 187-234). Amsterdam \& Philadelphia: John Benjamins.

Ryding, K. (2005). A Reference Grammar of Modern Standard Arabic. Cambridge: Cambridge University Press.

Sībawayh Abū Bišr 'Umar Ibn 'Uțmān (1988). Al-Kitāb I-II. Cairo Maktabat al-Xanchī.

Talmon, R. (1988). Al-kalam ma kana muktafiyan bi-nafsihi wa-huwa 1gumla": A Study in the history of sentence-concept and the Sibawaihian legacy in Arabic grammar. Zeitschrift der Deutschen Morgenländischen Gesellschaft, 138: 74-97

Thompson, G. (2006). Theme in Text. In K. Brown (Ed.), Encyclopedia of Language and Linguistics (PP. 658-668). Oxford: Elsevier Science.

Thompson, G. (2007). Unfolding theme: the development of clausal and textual perspectives on theme. In R. Hasan, C.M.I.M. Matthiessen, J. Webster (Eds.), Continuing Discourse on Language: functional perspectives, Volume2 (PP. 671-696), London: Equinox.

Thompson, G. (2013). Introducing Functional Grammar. 3rd ed. London NY: Routledge.

Versteegh, K. (2007). 'Inna wa-• axawatuha. In K. Versteegh ,M.Eid, A. Elgibali, M. Woidich,A. Zaborski (Eds.), Encyclopedia of Arabic Language and Linguistics, v. 2(PP. 354-358). Leiden \& Boston: Brill.

Versteegh, K. (2007). Isnad. In K. Versteegh ,M.Eid, A. Elgibali, M. Woidich,A. Zaborski (Eds.), Encyclopedia of Arabic Language and Linguistics, v.2(PP. 434-437). Leiden \& Boston: Brill.

Versteegh, K. (2014). The Arabic Language. $2^{\text {nd }}$ ed. Edinburgh: Edinburgh University Press.

Weiss, B. (1985). Subject and Predicate in the Thinking of the Arabic Philologists. Journal of the American Oriental Society, 105(4), 605-622. 